\title{
Effects of Different Commercial Feed on Water Quality and Survival of Clarias gariepinus (Burchell, 1822)Fingerlings
}

\author{
Jamabo, N. A. \& Dienye, H. E. \\ Department of Fisheries,Faculty of Agriculture,University of Port Harcourt, \\ Choba,Rivers State, Nigeria. \\ nenejamabo@yahoo.com
}

\begin{abstract}
The survival rate and water quality of African Catfish fingerlings (Clarias gariepinus) fed with four commercial feed (Top,Vital,Lynx and Coppens)feeds was studied with the aim of establishing the effect of these feeds on water quality and survival rate, for a period of 8 weeks. One hundred and eighty (180) fingerlings of Clarias gariepinus and four commercial feeds with varying crude proteins were used for the experiment. Water quality parameters analyzed indicated temperature varied from $26.38{ }^{\circ} \mathrm{C}$ to $27.05^{\circ} \mathrm{C}$ while $\mathrm{pH}$ and dissolved oxygen ranged from 3.91 to 6.49 and $4.70 \mathrm{mg} / \mathrm{l}$ to $6.49 \mathrm{mg} / \mathrm{l}$ respectively. The treatment shows that there is a significant difference in $\mathrm{pH}$, temperature and dissolved oxygen across the treatment $(p<0.05)$ while alkalinity showed significant difference across the treatment $(p<0.05)$. Survival rate showed Top feed $(100 \%)$ followed by Coppens feed (93.3\%) while the lowest was recorded in Vital feed (46.67\%).
\end{abstract}

Keywords: Commercial feed, treatment, water quality, survival

\section{INTRODUCTION}

Fish makes a vital contribution to the survival and health of a significant portion of the world's population. Fish is especially important in the nutrition of the developing world. In some part of the world, people derive as much as $75 \%$ of their daily protein from fish. The growing need for fish supply and increase awareness of aquaculture in Nigeria has led to remarkable investment in aquaculture in recent years. However, the growing population in the country posed a challenge, which requires more investment to fill in the supply gap of 1.6 million metric tons [1]. Fish is still the cheapest and most available source of animal protein in Nigeria, though the high cost of fish today is attributed to low supply caused by low productivity from the water bodies that are already overexploited due to reckless fishing methods [2]. For aquaculture to be highly successful in Nigeria there is need for good quality and affordable feed, which can also encourage small scale farmers in the field of aquaculture for sustainable production and also meet the demand for fish. The amount of feed consumed, age, body size and temperature are the most important factors that limit maximum growth of fish [3]. Water quality affects the general condition of cultured organism as it determines the health and growth conditions of cultured organism. The critical parameters are temperature, suspended solids and concentrations of dissolved oxygen, ammonia, nitrite, carbon dioxide and alkalinity [4]

\section{Materials ANd Methods}

\section{Study Area}

The study was conducted at the Demonstration Farm. Fisheries unit, University of Port Harcourt, Choba, Rivers State, Nigeria.

\section{Experimental Fish}

One hundred and eighty fingerlings of Clarias gariepinus were obtained from demonstration farm of the University of Port Harcourt. The fish were acclimatized for one week and during the period of acclimatization the fish were fed ad libitum [5] at 5\% body weight twice daily [6] with Coppens at $42 \%$ crude protein. Feed not consumed and fecal matters were siphoned out every day.At the end of the acclimatization period, the fish were randomly selected and stocked into 12 plastic tanks of $26 \mathrm{x}$ $27 \times 40 \mathrm{~cm}^{3}$ containing 30L of aerated water with each plastic tank holding 15 fish. Feeding was suspended 24 hours before the feeding trial to increase appetite and reception for new diet [7]. 


\section{Experimental Diet}

One imported (Coppens,) and three local (Vital, Top and Lynx feed) commercial feeds were obtained. The feeds contained different levels of crude protein- $42 \%, 45 \%, 42 \%$ and $42 \%$. Each test diet was fed to duplicate groups for 8 weeks. The feed/experimental diets were analysed for proximate composition according to [8].

\section{Experimental Procedure}

The temperature, $\mathrm{pH}$, dissolved oxygen and alkalinity of the plastic tanks were monitored on weekly basis. The initial weight and length of the fish at the commencement of the experiment and final weight and length was determined using meter weighing balance (model P168) and a calibrated meter rule. Weekly weight and length measurements were taken to monitor weight and length gain. Survival rate was calculated according to [9]

$$
\% \text { Survival rate }(\% \mathrm{SR})=\frac{\text { Final number of fish }}{\text { Initial number of fish }} \times 100
$$

Feed Conversion Ratio(FCR)=Weight of dry feed fed(g) X 100 [10]

Live weight gain of fish $(\mathrm{g})$

\section{RESULTS AND DiSCUSSION}

Table 1 shows the physico- chemical parameters of the different treatment. Treatment 4(Coppens feed) recorded the highest $\mathrm{pH}$ value of 7.20 while treatment 2(Vital feed) had the lowest $\mathrm{pH}$ value of 6.51.Temperature ranged between $26.38^{\circ} \mathrm{C}$ to $27.05^{\circ} \mathrm{C}$. Highest value of Dissolved Oxygen was recorded in treatment $4(6.49 \mathrm{mg} / \mathrm{l})$ and lowest in treatment $2(3.91 \mathrm{mg} / \mathrm{l})$ while alkalinity values range from $129.25 \mathrm{mg} / \mathrm{l}$ to $189.75 \mathrm{mg} / \mathrm{l}$. This shows that there is significant difference in $\mathrm{pH}$, temperature and dissolved oxygen across the treatment $(\mathrm{p}<0.05)$ while alkalinity show significant difference across the treatment $(\mathrm{p}<0.05)$. Table 2 shows the mean values of the growth parameters. Treatment 4; Coppens feed recorded the highestsize in length $(26.4 \mathrm{~cm})$ while treatment3 Lynx feed recorded the lowest $(17.73 \mathrm{~cm})$. The mean weight ranged from treatment $2(45.46 \mathrm{~g})$ with the highest to treatment $4(27.49 \mathrm{~g})$. Feed conversion ratio (FCR) in treatment $4(0.73)$ had the highest value while treatment 2(0.41) recorded the lowest value. The result shows that there is significant difference in length, weight and FCR across the treatments $(\mathrm{p}<0.05)$. Survival rate was at the highest in treatment 1 ; Top feed $(100 \%)$ while treatment 2 Vital feed had the lowest survival rate of $46.67 \%$. Table 3 shows the pearson correlation matrix between physico-chemical parameters, length and weight. Temperature and $\mathrm{pH}$ showed positive correlation to length and is significant at $\mathrm{p}<0.01$ while dissolved Oxygen(DO) is negatively correlated to temperature and length but weight showed a positive correlation to length and significant at $p<0.05$. There is positive correlation between length and weight and is significant at $\mathrm{p}<0.05$ while alkalinity showed no correlation between length and weight.

African catfish can tolerate temperatures as low as $6^{\circ} \mathrm{C}$ and as high as $50^{\circ} \mathrm{C}$ [11]. During the period of investigation, water temperature varied from $17.5-30^{\circ} \mathrm{C}$. [12] found highest growth of C. gariepinus at the temperature of $28-30^{\circ} \mathrm{C}$ whereas [13] found best result of C. gariepinus at temperature ranges from $24-29^{\circ} \mathrm{C}$. The range of water temperature recorded during the study period was quite stable and within the period of the experiment but the Dissolved Oxygen was low in treatment 2(3.91) and 3(4.70) which could be attributed to the feed quality.

The survival rate obtained in this study revealed that treatment 1 and 4 had the highest survival. The problem associated with the low survival rate in treatment 2 and 3 in this study arose due to the change in the physico-chemical parameters of the water as a result of the feed. Moreover, it was observed that the fingerlings showed loss of appetite in the 5th week of the study.

However, the result obtained from this study for survival rate is contrast to the findings of [14] on the growth performance of two African Catfish, of which the pure breds recorded $37.8 \%$ and $38.75 \%$ for pure crossbred C.gariepinus and H.longifilis respectively. Lovell [15]stated that protein quality of feed can affect the growth performance of fish and protein quality is affected by amino acid composition and digestibility. Although, Coppens and Durante feeds had higher crude protein (CP) content $(\mathrm{CP}=56 \%$ and 57\% respectively), least final mean weight and survival rates were obtained in them. This observation is in accordance with previous work on feeding trial [16]. It is important to 
Effects of Different Commercial Feed on Water Quality and Survival of Clarias Gariepinus (Burchell, 1822)Fingerlings

note that percentage of protein in feed determined by chemical analysis is not synonymous with the amount of protein available from feed stuff to the fish [16].

The pearson correlation matrix between physico chemical parameters, length and weight of C.gariepimus (Table 3), indicated a level of significant $(\mathrm{p}<0.01)$ between $\mathrm{pH}$ and length, while the relationship between the dissolved oxygen and length was at $\mathrm{p}<0.05$ level.

Table 1. Mean values of the Physico-chemical parameter of the treatment

\begin{tabular}{|l|l|l|l|l|l|}
\hline S. No & Feed & $\mathbf{p H}$ & Temperature $\left({ }^{\mathbf{C}} \mathbf{C}\right)$ & $\mathbf{D O}(\mathbf{m g} / \mathbf{l})$ & Alkalinity $(\mathbf{m g} / \mathbf{l})$ \\
\hline 1 & Top & $6.99^{\mathrm{b}}$ & $26.76^{\mathrm{b}}$ & $5.73^{\mathrm{a}}$ & $189.75^{\mathrm{a}}$ \\
\hline 2 & Vital & $6.51^{\mathrm{d}}$ & $26.38^{\mathrm{c}}$ & $3.91^{\mathrm{b}}$ & $129.25^{\mathrm{a}}$ \\
\hline 3 & Lynx & $6.80^{\mathrm{c}}$ & $27.05^{\mathrm{a}}$ & $4.70^{\mathrm{c}}$ & $131.25^{\mathrm{a}}$ \\
\hline 4 & Coppens & $7.20^{\mathrm{a}}$ & $26.94^{\mathrm{a}}$ & $6.49^{\mathrm{d}}$ & $167.58^{\mathrm{a}}$ \\
\hline & SEM & 0.044 & 0.617 & 0.304 & 3667.3 \\
\hline
\end{tabular}

*Superscripts of the same alphabet are not significantly different $(\mathrm{P}<0.05)$

**Superscripts of different alphabets are significantly different $(\mathrm{P}<0.05)$

Table2: Mean values of growth parameters

\begin{tabular}{|l|l|l|l|l|l|}
\hline S. No & Feed & Length $(\mathbf{c m})$ & Weight $(\mathbf{g})$ & FCR & Survival Rate (\%) \\
\hline 1 & Top & $19.85^{\mathrm{b}}$ & $32.68^{\mathrm{b}}$ & $0.58^{\mathrm{d}}$ & 100 \\
\hline 2 & Vital & $18.15^{\mathrm{c}}$ & $45.46^{\mathrm{a}}$ & $0.41^{\mathrm{a}}$ & 46.67 \\
\hline 3 & Lynx & $17.73^{\mathrm{c}}$ & $29.91 \mathrm{~b}^{\mathrm{c}}$ & $0.61^{\mathrm{c}}$ & 53.33 \\
\hline 4 & Coppens & $26.44^{\mathrm{a}}$ & $27.49^{\mathrm{c}}$ & $0.73^{\mathrm{b}}$ & 93.33 \\
\hline & SEM & 7.368 & 31.254 & 0.448 & 123.98 \\
\hline
\end{tabular}

*Superscripts of the same alphabet are not significantly different $(\mathrm{P}<0.05)$

**Superscripts of different alphabets are significantly different $(\mathrm{P}<0.05)$

Table3: Pearson's correlation matrix between physico-chemical parameters, length and weight

\begin{tabular}{|l|l|l|l|l|l|l|l|l|}
\hline & Week & Treatment & $\mathrm{pH}$ & $\begin{array}{l}\text { Temperature } \\
\left({ }^{\circ} \mathrm{C}\right)\end{array}$ & $\begin{array}{l}\text { Dissolved } \\
\text { Oxygen } \\
(\mathrm{Mg} / \mathrm{l})\end{array}$ & $\begin{array}{l}\text { Alkalinity } \\
(\mathrm{Mg} / \mathrm{l})\end{array}$ & $\begin{array}{l}\text { Length } \\
(\mathrm{cm})\end{array}$ & $\begin{array}{l}\text { Weight } \\
\text { (grams) }\end{array}$ \\
\hline Week & 1 & & & & & & & \\
\hline Treatment & .000 & 1 & & & & & & \\
\hline $\mathrm{pH}$ & $.305^{* *}$ & $.253^{*}$ & 1 & & & & & \\
\hline Temperature & .109 & .186 & .381 & 1 & & & & \\
\hline $\begin{array}{l}\text { Dissolved } \\
\text { Oxygen }\end{array}$ & -.181 & -.557 & -178 & $-.204^{*}$ & 1 & & & \\
\hline Alkalinity & .126 & -.035 & .180 & .069 & -.161 & 1 & & \\
\hline Length & $.597^{* *}$ & $.327^{* *}$ & $.367^{* *}$ & .069 & $-.217^{*}$ & .127 & 1 & \\
\hline Weight & $.697^{* *}$ & $-.259^{*}$ & -.050 & -.133 & -.071 & .041 & $.261^{*}$ & 1 \\
\hline
\end{tabular}

$* *$ Significant at $\mathrm{p}<0.01 *$ Significant at $(\mathrm{p}<0.05)$

\section{Conclusion}

The result of this experiment showed that fingerlings fed with different commercial feed has an effect on the physico-chemical parameters of the water. The best water quality and survival rate was observed with Coppens feed and Top feed while Vital feed has the least water quality and survival rate. Therefore, it is necessary to consider the prevailing physico-chemical characteristic that affects fish feeding behavior, survival and its utilization. The success of Clarias gariepinus fingerlings depends on quality feed and water for better growth.

\section{REFERENCES}

[1] Fishnetwork (2009). Positioning the Fisheries Sub-Sector for Vision 20-2020 A quarterly Publication of the Fisheries Society of Nigeria (FISON) Vol.5 No. 4 Jan-Mar 2009.

[2] Adesulu E. A, Olaleye W. F, Akinpelu A. I (2004). Pisciculture Essential Production Information._University of Ibadan Press, Ibadan, Nigeria. pp. 10-25. 
[3] Machiels M. A. M,Henken A. M (1985). Growth rate, feed utilization and energy metabolism of the African Catfish, Clarias gariepinus (Burchell, 1822) as affected by dietary protein energy content. Aquaculture, 44:271-284

[4] Timmons M. B, James M. E, Fred W. W, Sreven T. S, Brian J. V.(2001). Recirculating Aquaculture Systems. NRAC publication No.01-002.

[5] Anibeze C. I. P, Eze A (2000). Growth response of two African Catfishes (Osteichthys: Clariidae) in Homestead concrete ponds. Journal of Aquatic Sciences, 15:55-58.

[6] Okoye F. C, Eyo A. A,Aminu N. G (2001). Growth of Tilapia Oreochromis niloticus hybrid fingerlings fed lipid-based diets. In: Fish Nutrition and Fish Feed Technology, A.A. Eyo(Ed.). Proceedings of the First National Symposium of Fish Nutrition and Fish Feed Technology held at NIOMAR Lagos, pp52-57

[7] Madu C. T,Akilo K. T. (2001). The use of live maggot and live tilapia fry as unconventional diets for Juveniles of the catfish Clarias anguillaris L. In: Fish Nutrition and Fish Feed Technology, A.A. Eyo(Ed.). Proceedings of the First National Symposium of Fish Nutrition and Fish Feed Technology held at NIOMR Lagos, pp 75-83

[8] Association of Official Analytical Chemists (AOAC 1999). Official Methods of Analysis, 14th ed. Williams (ed) Arlington V.A. p 102

[9] Pascal G. V. D, NieuwegiessenA. J. V, JohanJ, Johan W. S.(2006).The effect of stocking density on welfare indicators in African Catfish Clarias gariepinus(Burchell)AQUA Meeting,p.184

[10] Benedict O. O,GabrielU. I, EzekielO. A.(2005).Effect of stocking size of the predatory African Catfish(Heterobranchus longifilis)on the growth performance of Nile Tilapia

(Oreochromis niloticus) in pond culture. International Journal of Fisheries and Aquaculture, 1(3):38-43

[11] Babiker M. M.(1984). Aspects of the biology of the catfish Clarias lazera related to its Economic cultivation. Hidrobiologia, 110: 295-304.

[12] Mollah M. F. A.(1984). Effect of water temperature on the growth and survival of catfish (Clarias macrocephalus) larvae.Indian Journal of Fish.,31(1): 66-73.

[13] Henken A. M,Machiels M. A. M, Deeker W, Hogendoorn H. (1986). The effect of dietaryprotein and energy content on growth rate and feed utilization of the African catfish, Clarias gariepinus (Burchell).Aquaculture, 58: 55-74.

[14] Ataguba G. A, AnnuneP. A, Ogbe F. G. (2010). Growth performance of two African catfish C.gariepius and $H$. longifilis and their hybrids in plastic aquaria.Livestock Research for Rural Development.22(2):16.

[15] Lovell R. T.(1989). Nutrition and feeding of fish, An AVI Book, Van Nostrand-Reinhold, New York. ; 260

[16] YakubuA. F, OkonjiV. A, NwoguN. A, OlajiE. D, Ajiboye O. O, Adams T. E.(2013). Effect ofstocking density on survival and body composition of Nile tilapia (Oreochromis niloticus) fed multi feed and NIOMR feed in semi flow-through culture systems. Jour NatSci Res.;3(14):2937.

\section{AUTHOR'S BIOGRAPHY}

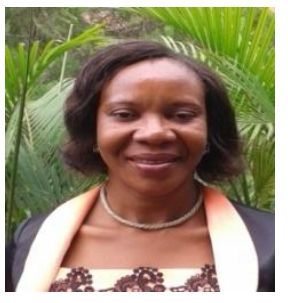

Dr. (Mrs.) Nene Amabere Jamabo, is a Lecturer in the Department Fisheries. Her research area includes fisheries management and sustainable aquaculture. Her major contribution to knowledge is on the ecology and culture of Tympanotonus fuscatus var fuscatus. She has equally done extensive research onfish seed production for freshwater and brackish water species, and other ecological studies on the aquatic ecosystem of the Niger Delta Area, Nigeria. She was the past $4^{\text {th }}$ Vice President of Fisheries Society of Nigeria (FISON) and coordinated preparatory duties for all FISON's activities as they affect Research, Training/Capacity Building, Resource Surveys and Studies. She has travelled extensively for aquaculture conferences in different countries -the United States of America, Germany, Mexico, Brazil, and Ethiopia. She is also an Associate Editor of Maxwell Scientific Publication; and has published several works in both local and international journals.Dr. (Mrs.) Nene Amabere Jamabo is a practicing farmer and consults for several organizations on aquaculture and sustainable development. She has trained over 6,000 women and youths in fish farming techniques. She is also involved in career development in secondary schools on the topic "promising agriculturists. 